\title{
Solid phase extraction of copper traces using poly(styrene-divinylbenzene) membrane disks modified with pyridoxal salicyloylhydrazone in water samples
}

\author{
M. Díaz-de Alba, M.D. Galindo-Riaño*, M. García-Vargas \\ Faculty of Sciences, Department of Analytical Chemistry, University of Cádiz, Campus Río S. Pedro, 11510 Puerto Real, Cádiz, Spain
}

\section{A R T I C L E I N F O}

\section{Article history:}

Received 2 May 2012

Received in revised form

8 August 2012

Accepted 9 August 2012

Available online 18 August 2012

\section{Keywords:}

Copper

Water analysis

Solid phase extraction

Poly(styrene-divinylbenzene) membrane disks

Pyridoxal salicyloylhydrazone

\begin{abstract}
A B S T R A C T
A simple technique for the isolation, concentration and matrix simplification of $\mathrm{Cu}(\mathrm{II})$ ion in natural waters is proposed. This method has been developed using poly(styrene-divinylbenzene) membrane disks modified with the synthesized ligand pyridoxal salicyloylhydrazone (PSH). The retained ions on the disks were eluted with $10 \mathrm{~mL} 1 \mathrm{~mol} \mathrm{~L}^{-1} \mathrm{HNO}_{3}$ and measured by flame atomic absorption spectrometry at $324.8 \mathrm{~nm}$. The influence of $\mathrm{pH}$, amount of ligand, type and amount of eluent for the stripping of copper ion from the membrane over extraction efficiency were evaluated. Extraction efficiencies $>99 \%$ were obtained by elution of the disks with minimal amount of solvent with a preconcentration factor up to 100 . The precision of the method for 10 replicate measurements of aqueous solutions containing $40 \mu \mathrm{g} \mathrm{L}^{-1} \mathrm{Cu}(\mathrm{II})$ was $1.5 \%$ at significance level of $95 \%$. The breakthrough volume for $5 \mu \mathrm{g}$ of $\mathrm{Cu}(\mathrm{II})$ was found to be $1000 \mathrm{~mL}$ and the detection limit of the method was $4 \mathrm{ng} \mathrm{L}^{-1}$ of metal ion. The present method was successfully applied to the extraction and determination of copper in lake and sea waters.
\end{abstract}

(c) 2012 Elsevier B.V. All rights reserved.

\section{Introduction}

The separation and isolation of low levels of copper from natural waters and its determination has special importance. Copper is a ubiquitous trace metal and occurs in soil, water, air and in the biosphere. Natural waters (pristine streams, rivers and lakes) contain $0.5-200 \mu \mathrm{g} \mathrm{L}^{-1}$ total dissolved copper. Coastal, bays and estuary waters contain copper concentration from about $0.0069-20.0 \mu \mathrm{g} \mathrm{L}^{-1}$ and ocean water contains $0.0063-2.8 \mu \mathrm{g} \mathrm{L}^{-1}$ [1]. Copper is an essential and necessary micronutrient for many biological systems at very low levels. However, it becomes toxic at high levels due to its association with cell membranes, preventing the transport across the wall cell. Spectrophotometric methods and flame atomic absorption spectrometry (FAAS) [2-4] are very available techniques in many laboratories so they are frequently used for determination of heavy metals, such as copper. FAAS is usually less subjected to interferences than electrothermal atomic absorption (ETAAS) or inductivelycoupled plasma mass spectrometry (ICP-MS) (difficulties in the determination are caused by matrix interferences, principally high salt content). However, its sensibility can be insufficient with some environmental samples containing subtraces amounts of copper (detection limit of $0.02 \mathrm{mg} \mathrm{L}^{-1}$ copper in water without interferences

\footnotetext{
* Corresponding author. Tel.: + 34956 016362; fax: + 34956016460.

E-mail address: dolores.galindo@uca.es (M.D. Galindo-Riaño).
}

by EPA method 220.1 (Methods for the Chemical Analysis of Water and Wastes (EPA/600/4-79/020)). Consequently, a separation, preconcentration and matrix simplification step prior to copper determination by FAAS is normally necessary.

Many preconcentration techniques have been widely used for copper analysis in environmental samples, liquid-liquid extraction, coprecipitation, ion-pair extraction and liquid membrane technology [5-8]. These classical methods of extraction are labor intensive and time-consuming. Furthermore, the majority of these techniques consume relatively large volumes of highpurity solvents with expensive disposal requirements, and the subsequent removal of solvents causes many environmental problems.

The solid phase extraction method (SPE) can solve these disadvantages. SPE is a rapid and simple technique for the isolation, preconcentration and matrix simplification of selected analytes in samples with unfavorable properties for direct analysis to achieve increased sensitivity in the analytical process. It is an attractive alternative for the classical solvent-solvent extraction methods, due to its low costs, shorter processing times, simpler processing procedures and low consumption of and exposure to solvent and it has received much attention in recent years for the analysis of trace metals in environmental samples. In SPE the water sample passes through the solid phase, which consists of particulate sorbent packed into columns of short length (usually called "cartridges") or immobilized in the form 
of a thin disk. During the process, the analytes are retained onto the solid phase and eluted from the sorbent with a suitable solvent.

Recently, the SPE disks and cartridges have been successfully used for the separation and determination of metal ions in some types of natural waters. Carbon nanotubes cartridges have been used in order to preconcentrate copper from water samples prior to its analysis by FAAS [9]. Likewise Al, Cd, Cu, Fe, Mn, Ni, Pb, Sn, V and $\mathrm{Zn}$ in seawater have been analyzed by preconcentrating in cartridges and ICP-optical emission spectrometry determination [10]. By contrast, SPE disks have been frequently used to preconcentrate so many metallic ions in water samples, like nickel, iron and copper before their determination by FAAS [11-13] or silver and nickel in natural waters prior to their analysis by diffuse reflectance spectroscopy $[14,15]$. Both formats (cartridges and disks) use the same sorbent technology, but disks offer many advantages that favor their use for some applications: disks work better for large sample volumes containing suspended particles because of their larger cross-sectional area that provides shorter sample processing times; the use of smaller particles and the grater mechanical stability of disks minimize channeling that can occur in cartridges due to their lower packing density. In summary, the thin bed mass of the disk provides these performance gains: minimization of solvents and sample volumes, high throughput, small elution volumes, ability to eliminate the evaporation step, sample processing at maximal flow rates without channeling and consistent recoveries.

There are many kinds of sorbent for disks: octadecylsiloxane (C18) and octylsiloxane-bonded silica (C8) (for extraction of non-polar and moderately polar compounds), poly(styrenedivinylbenzene) (SDB) (for compounds poorly extracted by octadecylsiloxane-bonded silica sorbents and soluble in water), activated carbon (less frequently used), mixed mode, sulphonic acid and quaternary amine ion exchangers (for the selective isolation of ionic and easily ionisable compounds),... [16]. For metal ions in water samples, octadecylsiloxane-bonded silica and poly(styrene-divinylbenzene) disks are commonly used (e.g., SDB disks have been used to the trace analysis of silver, nickel, copper, iron and chromium $[14,15,17]$ and C18 disks have been utilized for the analysis of nickel, iron, copper, silver and cadmium $[11-13,18,19])$. SDB disks have the important advantage of being stable in the whole range of $\mathrm{pH}$. The selectivity of the disks can be improved by immobilization of suitable reagents onto the solid sorbent.

The aim of this work was the use of pyridoxal salicyloylhydrazone (PSH) reagent as a selective modifying agent of the SDB membrane disk for the highly selective extraction, preconcentration and determination of very low trace amounts of copper ion in water samples with different saline matrix by FAAS. Heterocyclic hydrazones, including PSH, are an important group of ligands which have attracted attention on medicinal chemists due to their remarkable antiviral and antimalarial effects, iron scavenging and antitubercular activities. These biological activities are based on their ability to form stable chelates with the transition metal ions [20] which can be retained on disks.

\section{Experimental}

\subsection{Reagents and solutions}

All reagents and solvents were of the highest purity available (pro analysis or Suprapur grade) and all aqueous solutions were prepared using Milli-Q deionised water (Millipore, USA).

Standard solutions of copper were prepared by dilution of $1000 \mathrm{mg} \mathrm{L}^{-1}$ AS (atomic spectroscopy) standard solution from
Merck (Darmstadt, Germany) in $0.05 \mathrm{~mol} \mathrm{~L}^{-1} \mathrm{HNO}_{3}$. The synthesis of PSH has been described previously [21] using salicyloyhydrazide and pyridoxal hydrochloride (Sigma-Aldrich, Steinheim, Germany). Crystals obtained were filtered off and washed with a large volume of ethanol. Subsequently, they were re-crystallized from $1: 1$ ethanol/water and dried at $110{ }^{\circ} \mathrm{C}$ with a yield of $80 \%$. The reagent obtained was yellow $\left(\mathrm{C}_{15} \mathrm{H}_{15} \mathrm{~N}_{3} \mathrm{O}_{4}\right.$, formula weight, 301; m.p., $247^{\circ} \mathrm{C}$; CAS No.: 82970-90-9).

The $\mathrm{pH}$ values of sample solutions (range 3.5-5.5) were adjusted using acetate buffer $\left(4 \mathrm{~mol} \mathrm{~L}^{-1}\right)$ prepared with acetic acid and sodium hydroxide of Suprapur grade (Merck, Darmstadt, Germany). After adjustment of $\mathrm{pH}$, the final concentration of buffer in sample solutions was $0.4 \mathrm{~mol} \mathrm{~L}^{-1}$.

The proposed method was applied to coastal water samples from southwest coast of Spain (Huelva Estuary). They were filtered in situ using $0.45 \mu \mathrm{m}$ Calyx Capsule MSI filter (3/8" barb, $1 / \mathrm{PK}$, polypropylene; Osmonics, USA) connected on line with the Tygon tubes. $500-\mathrm{mL}$ portions of samples were acidified with $2 \mathrm{~mL} \mathrm{~L}^{-1} \mathrm{HNO}_{3}$ of Suprapur grade (Merck Darmstadt, Germany), kept to room temperature during one week, and after stored at $-18{ }^{\circ} \mathrm{C}$ until analysis. Before analysis, organic matter of samples was destroyed by adding of $0.02 \mathrm{~mol} \mathrm{~L}^{-1}$ Suprapur hydrogen peroxide (Merck, Darmstadt, Germany) and UV digestion for three hours employing a $500 \mathrm{~W}$ high pressure mercury vapour lamp.

\subsection{Apparatus}

Metal ion measurements were performed by atomic absorption spectroscopy (AAS) using a Solaar-M Series spectrometer (Unicam, UK), with a hollow cathode lamp at a wavelength of $324.8 \mathrm{~nm}$ using an adjusted air-acetylene flame and a deuterium background corrector. A model 2001 pH-meter equipped with 52-02 combined glass- $\mathrm{Ag} / \mathrm{AgCl}$ electrode (Crison, Spain) was used for $\mathrm{pH}$ measurements. Extractions were carried out on a standard Millipore 47-mm filtration apparatus connected to a D95 model DINKO vacuum pump.

\subsection{Sample extraction}

Extractions were performed with $47 \mathrm{~mm}$ diameter $\times 0.5 \mathrm{~mm}$ thickness 3M-Empore ${ }^{\mathrm{TM}}$ SDB-XC membrane disks containing poly(styrene-divinylbenzene) (16- $\mu \mathrm{m}$ particles, $80-\AA$ pure size). The typical composition of the disks is $90 \% w / w$ poly(styrenedivinylbenzene) and $10 \% w / w$ PTFE fibers and their surface area is $450 \mathrm{~m}^{2} \mathrm{~g}^{-1}$. The structure of SDB-XC provides unique selectivity, especially in the retention of moderately polar analytes and displaying aromatic interactions allowing the retention of PSH.

Before sample extraction, a preconditioning step, cleaning and conditioning of disks were carried out in order to ensure an optimal extraction of copper ion. Thus, after installing the membrane disk in the filtration apparatus, it was rinsed with $5 \mathrm{~mL}$ methanol with the aim of preconditioning the disk and making the pass of following solvents easier. Cleaning step consisted in washing the membrane disk with $10 \mathrm{~mL}$ of a $1 \mathrm{~mol} \mathrm{~L}^{-1} \mathrm{HNO}_{3}, 10 \mathrm{~mL}$ methanol and $10 \mathrm{~mL}$ acetonitrile by applying a slight vacuum to remove all metallic and organic contaminants that could come from manufacturing process and the environment. After all the solvents had passed through the disk, it was dried by passing air for a few minutes. Conditioning step began by introducing $2.5 \mathrm{mg}$ of PSH dissolved in $2.5 \mathrm{~mL}$ of methanol to the reservoir of the apparatus. This solution was drawn slowly through the disk without vacuum so that the whole disk surface was soaked. When the ligand had completely penetrated inside the membrane and methanol had been evaporated at room temperature, the disk was washed with $25 \mathrm{~mL}$ of water under vacuum and dried by passing air through it. By this 
way, the membrane disk was modified by PSH and ready for sample extraction.

The general procedure for the extraction of $\mathrm{Cu}$ (II) ions from aqueous samples was as follows: the modified membrane disk was washed with $25 \mathrm{~mL}$ of water in order to prewet its surface before the extraction of $\mathrm{Cu}(\mathrm{II})$ ions. Then, $500 \mathrm{~mL}$ of the sample solution containing $20 \mu \mathrm{g}$ of $\mathrm{Cu}(\mathrm{II})$ adjusted to a $\mathrm{pH} 4.5$ was passed through the disk under vacuum to maintain a flow rate of $10 \mathrm{~mL} \mathrm{~min}{ }^{-1}$. The surface of the disk must be wet during all extraction process. After the extraction, bulk water was removed from the disk and the apparatus by sucking air through the disk under full vacuum for about $3 \mathrm{~min}$. With this procedure, copper ions are quantitatively adsorbed on the modified disk. After the extraction, the adsorbed copper was stripped from the modified membrane disk using $10 \mathrm{~mL}$ of $1 \mathrm{~mol} \mathrm{~L}^{-1} \mathrm{HNO}_{3}$ at a flow rate of $5 \mathrm{~mL} \mathrm{~min}^{-1}$. The copper concentration was determined at $324.8 \mathrm{~nm}$ by FAAS.

In order to re-use the disk, a last cleaning step was carried out. Thus, the membrane disk was rinsed with $10 \mathrm{~mL}$ of $1 \mathrm{~mol} \mathrm{~L}^{-1}$ $\mathrm{HNO}_{3}, 10 \mathrm{~mL}$ of methanol and $10 \mathrm{~mL}$ of water by appling vacuum until the disk was completely dried before storing.

\section{Results and discussion}

PSH is a multidentate ligand with the chromogenic group $(\mathrm{OH}) \mathrm{C}-\mathrm{C}-\mathrm{CO}-\mathrm{NH}-\mathrm{N}-\mathrm{C}-\mathrm{C}(\mathrm{OH})$ (Fig. 1) with a low solubility in water $\left(0.6 \mathrm{~g} \mathrm{~L}^{-1}[22]\right)$. The ligand has an acid-base behaviour with two ionisation constants of $p K_{1}=4.0$ and $p K_{2}=7.9$, caused by protonation of the pyridine nitrogen atom and deprotonation of the hydroxyl group, respectively. It can be bonded to different transition metals, like $\mathrm{Al}(\mathrm{III}), \mathrm{Cu}(\mathrm{II}), \mathrm{Ni}(\mathrm{II}), \mathrm{Ti}(\mathrm{IV})$ and $\mathrm{Zr}(\mathrm{IV})$, producing very stable complexes $[21,23,24]$. This reagent has been used in the spectrophotometric determination of several metals as nickel, zinc, iron or zirconium and in the stripping voltammetric determination of nickel [25], but nothing has been previously reported about the use as a potential modifier of membrane disks. In this study, PSH has been proposed for copper determination because of its good binding capacity to this ion.

The continuous variation (Job's method) and the mole ratio methods were applied in order to establish the stoichiometry of the $\mathrm{Cu}(\mathrm{II})-\mathrm{PSH}$ complex. Methanol solutions of copper chelate buffered at pH 4.5 were prepared and their absorbances were measured at $420 \mathrm{~nm}$ with visible spectrophotometer. The copper/ PSH ratio was found to be $2: 3$.

Some preliminary experiments were performed in order to investigate the quantitative retention of $\mathrm{Cu}(\mathrm{II})$ ions by poly (styrene-divinylbenzene) membrane disks in the absence and presence of PSH. It was found that, while the membrane disk itself did not show any tendency for the retention of $\mathrm{Cu}(\mathrm{II})$ ions $(<1 \%$ ), the membrane disk modified by PSH was capable to quantitatively retain $\mathrm{Cu}$ (II) ions in the sample solution.

The efficiency of this proposed method was first determined with a set of preliminary experiments in order to acquire information about chemical and instrumental variables using the univariate model. The variables studied were the type and concentration of eluent, $\mathrm{pH}$ of the sample, flow rate and amount of PSH. Afterwards, a<smiles>Cc1ncc(CO)c(/C=N/NC(=O)c2ccccc2O)c1O</smiles>

Fig. 1. Structure of pyridoxal salicyloylhydrazone. fractional factorial design $3^{3-1}$ [26] was applied to optimise the extraction conditions using this multivariate method.

\subsection{Preliminary studies}

\subsubsection{Choice of eluent}

In order to choose the most effective eluent the retained copper ions were stripped with varying concentrations of different acids. The recovery for samples containing $20 \mu \mathrm{g}$ of $\mathrm{Cu}(\mathrm{II})$ in a $500 \mathrm{~mL}$ solution at pH 4.5 using $5 \mathrm{mg}$ of PSH are summarized in Table 1. The quantitative elution of copper from the modified membrane disk could be accomplished by using $5-10 \mathrm{~mL}$ of $0.5 \mathrm{~mol} \mathrm{~L}^{-1} \mathrm{HCl}$, or $10 \mathrm{~mL}$ of $1 \mathrm{~mol} \mathrm{~L}^{-1} \mathrm{HCl}$. Also, $10 \mathrm{~mL}$ of 1-2 $\mathrm{mol} \mathrm{L}^{-1} \mathrm{HNO}_{3}$ were adequate. Acetic acid could not produce a quantitative stripping of these metallic ions, even at high concentrations. Subsequent quantitative elutions of the complex were carried out with 5-10 mL of $1 \mathrm{~mol} \mathrm{~L}^{-1} \mathrm{HNO}_{3}$ rather than $\mathrm{HCl}$ because nitrate ion is reported to be a more acceptable matrix for FAAS and ETAAS measurements than chloride [27].

\subsubsection{Effect of $p H$ on the adsorption of $\mathrm{Cu}(\mathrm{II})$}

The effect of $\mathrm{pH}$ of test solutions on the copper recovery using a modified disk with $5 \mathrm{mg}$ of PSH was studied as follows: $500 \mathrm{~mL}$ solutions containing $20 \mu \mathrm{g} \mathrm{Cu}(\mathrm{II})$ were adjusted in the $\mathrm{pH}$ range 3.5-5.5 by using $4 \mathrm{~mol} \mathrm{~L}^{-1}$ acetic acid/sodium acetate buffers. The resulting solutions were passed through the modified membranes and then stripped with $10 \mathrm{~mL}$ of $1 \mathrm{~mol} \mathrm{~L}^{-1} \mathrm{HNO}_{3}$. The obtained results are shown in Fig. 2. Maximum retention of metal was achieved at the $\mathrm{pH}$ range of 4.5-5. The progressive decrease of copper recovery at $\mathrm{pH}<4.5$ is probably due to weak complex formation of copper with immobilized PSH on solid phase particles

Table 1

Copper ions recovery from the modified membrane disks using different stripping acid solutions (samples contained $20 \mu \mathrm{g} \mathrm{Cu}^{2+}$ ions in $500 \mathrm{~mL}$ water at $\mathrm{pH} 4.5$ ).

\begin{tabular}{|c|c|c|c|}
\hline \multirow[t]{2}{*}{ Stripping acid solution } & \multicolumn{3}{|c|}{$\%$ Recovery for each acid concentration ${ }^{a}$} \\
\hline & $0.5 \mathrm{~mol} \mathrm{~L}^{-1}$ & $1 \mathrm{~mol} \mathrm{~L}^{-1}$ & $2 \mathrm{~mol} \mathrm{~L}^{-1}$ \\
\hline $10 \mathrm{~mL} \mathrm{HNO}_{3}$ & 93.2 & 101.0 & 102.1 \\
\hline $5 \mathrm{~mL} \mathrm{HNO}_{3}$ & 91.7 & 95.7 & 93.7 \\
\hline $10 \mathrm{~mL} \mathrm{HCl}$ & 100.7 & 101.4 & 96.4 \\
\hline $5 \mathrm{~mL} \mathrm{HCl}$ & 100.3 & 96.8 & 95.7 \\
\hline $10 \mathrm{~mL} \mathrm{CH}{ }_{3} \mathrm{COOH}$ & 7.1 & 28.0 & 83.4 \\
\hline
\end{tabular}

${ }^{\text {a }}$ R.S.D. $\leq 1.2 \%$ for three replicate experiments.

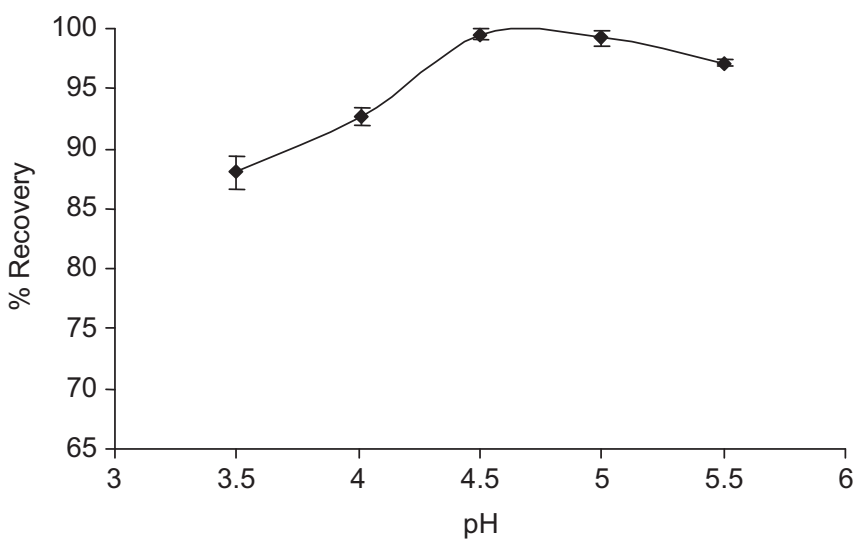

Fig. 2. Effect of aqueous phase $\mathrm{pH}$ on extraction of copper ion (conditions: $\mathrm{Cu}(\mathrm{II})$ amount $=20 \mu \mathrm{g}$; sample volume $=500 \mathrm{~mL}$; eluent $=10 \mathrm{~mL}$ of $1 \mathrm{~mol} \mathrm{~L}^{-1} \mathrm{HNO}_{3}$; immobilised PSH amount $=5 \mathrm{mg} ; n=3$ ). 
and the possible $\mathrm{Cu}$ ions precipitation at basic $\mathrm{pH}$ values [28]. Therefore, a pH 4.5 was chosen for the following determinations.

\subsubsection{Effect of flow rates}

The influence of flow rates of the sample and stripping solutions on the preconcentration method was investigated. It was found that adsorption of the metal ion was quantitative and reproducible in the range $10-20 \mathrm{~mL} \mathrm{~min}^{-1}$. Thus, the flow rate of sample selected for all studies was $10 \mathrm{~mL} \mathrm{~min}^{-1}$. On the other hand, quantitative stripping of copper ions from the disk was achieved in a flow rate range of $1-10 \mathrm{~mL} \mathrm{~min}^{-1}$ using $10 \mathrm{~mL}$ of $1 \mathrm{~mol} \mathrm{~L}^{-1} \mathrm{HNO}_{3}$. At higher values of flow rate, greater volumes of nitric acid are necessary to reach a quantitative stripping. Because of it, the flow rate during the stripping was maintained at $5 \mathrm{~mL} \min ^{-1}$ throughout the experiments.

\subsubsection{Effect of PSH amount}

In order to investigate the amount of PSH on the quantitative recovery of $\mathrm{Cu}$ (II) by the membrane disk, the solid-phase extraction was conducted by varying the amount of ligand from 0 to $7.5 \mathrm{mg}$ using $1 \mathrm{mg} \mathrm{mL}^{-1}$ PSH solutions in methanol (Fig. 3). The extraction of copper ions was quantitative above $2.5 \mathrm{mg}$ of ligand. Hence, for subsequent studies $2.5 \mathrm{mg}$ PSH sorbed on SDB disk was used.

\subsection{Experimental design: Multivariate optimisation}

To select the optimum conditions for $\mathrm{pH}$, volume and concentration of the eluent, a reduced factorial design was employed (fractional factorial design $3^{3-1}$ ). With this type of design the factors can be efficiently evaluated using a small fraction of the experiments of the full factorial design [26]. A total of ten experiments were carried out including three repetitions of the central point. The variables were studied at three levels, high, medium and low, denoted by $(+1),(0),(-1)$, respectively. The different variables and levels evaluated and the Pareto chart are shown in Table 2 and Fig. 4, respectively. The results of each experiment can be found in Table 3 .

According to the Pareto chart, it can be concluded that the $\mathrm{pH}$ showed a significant quadratic positive effect at confidence level of $95 \%$ being 4.5 the optimum value. Three-dimensional (3D) plots for the measured responses were formed based on the model polynomial functions to assess the change of the response surface. The relationship between the response ( $\mathrm{Cu}$ ions recovery) and the independent variables $\left(\mathrm{pH}\right.$, volume and concentration of $\left.\mathrm{HNO}_{3}\right)$ can be also understood by these plots. In Fig. 5 it can be seen that the higher recovery is obtained when $\mathrm{pH} 4.5$ and $10-15 \mathrm{~mL}$ of $\mathrm{HNO}_{3}$

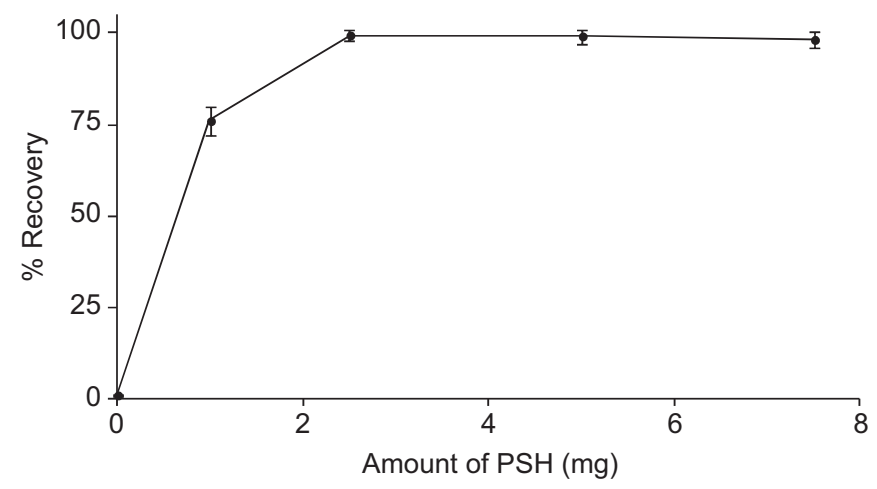

Fig. 3. Effect of immobilised PSH amount on extraction of copper ion (conditions: $\mathrm{Cu}(\mathrm{II})$ amount $=20 \mu \mathrm{g}$; sample volume $=500 \mathrm{~mL}$; $\mathrm{pH}=4.5$; eluent $=10 \mathrm{~mL}$ of $\left.1 \mathrm{~mol} \mathrm{~L}^{-1} \mathrm{HNO}_{3} ; n=3\right)$.
Table 2

Factor levels and selected values for the fractional factorial design $3^{3-1}$ (samples containing $20 \mu \mathrm{g} \mathrm{Cu}^{2+}$ ions in $500 \mathrm{~mL} ; 2.5 \mathrm{mg}$ of immobilised PSH on the disk).

\begin{tabular}{llll}
\hline Variable & $\begin{array}{l}\text { Low level } \\
(-1)\end{array}$ & $\begin{array}{l}\text { Medium level } \\
(0)\end{array}$ & $\begin{array}{l}\text { High level } \\
(+1)\end{array}$ \\
\hline $\begin{array}{l}\text { Volume of } \mathrm{HNO}_{3}(\mathrm{~mL}) \\
\text { pH of the sample }\end{array}$ & 5 & 10 & 15 \\
$\begin{array}{l}\text { Concentration of } \mathrm{HNO}_{3} \\
\left(\mathrm{~mol} \mathrm{~L}^{-1}\right)\end{array}$ & 3.5 & 4.5 & 5.5 \\
\hline
\end{tabular}

Table 3

Variable levels and results of the experimental design $3^{3-1}$ (random order for experiments).

\begin{tabular}{rcrll}
\hline Experiment & $\begin{array}{l}\text { Volume of } \\
\mathrm{HNO}_{3}(\mathrm{~mL})\end{array}$ & $\mathrm{pH}$ & $\begin{array}{l}\mathrm{HNO}_{3} \text { concentration } \\
\left(\mathrm{mol} \mathrm{L}^{-1}\right)\end{array}$ & $\begin{array}{l}\% \mathrm{Cu} \\
\text { recovery }\end{array}$ \\
\hline 2 & 5 & 4.5 & 1.5 & 77.6 \\
5 & 10 & 4.5 & 1 & 99.4 \\
3 & 5 & 5.5 & 1 & 70.3 \\
8 & 15 & 4.5 & 0.5 & 86.5 \\
4 & 10 & 3.5 & 1.5 & 64.2 \\
7 & 15 & 3.5 & 1 & 72.8 \\
6 & 10 & 5.5 & 0.5 & 67.6 \\
9 & 15 & 5.5 & 1.5 & 73.1 \\
1 & 5 & 3.5 & 0.5 & 76.2 \\
10 & 10 & 4.5 & 1 & 99.2 \\
11 & 10 & 4.5 & 1 & 99.5 \\
\hline
\end{tabular}

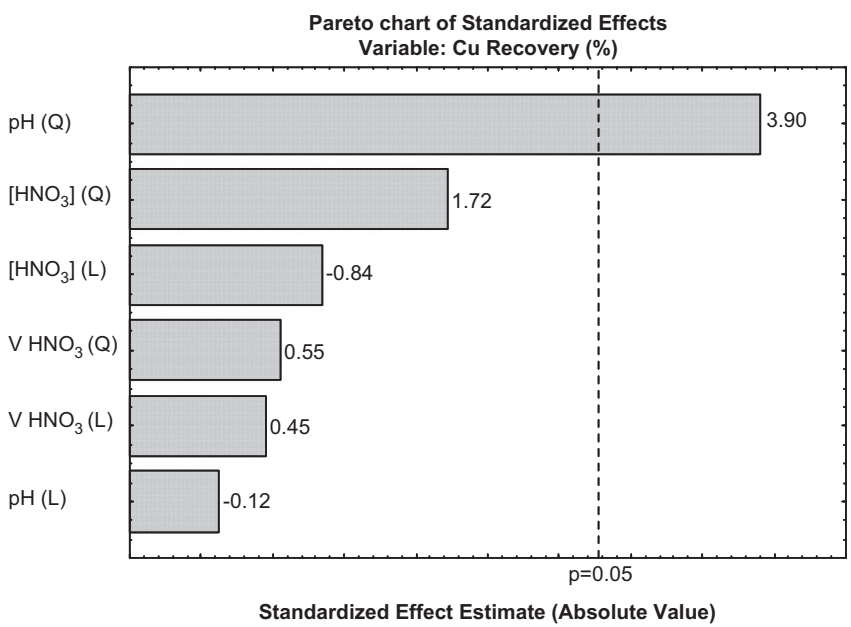

Fig. 4. Pareto chart for fractional factorial design $3^{3-1}$.

are used. In Fig. 6 the best response is achieved when pH 4.5 and $1 \mathrm{~mol} \mathrm{~L}^{-1} \mathrm{HNO}_{3}$ are used. Fig. 7 shows the maximum recovery for $1 \mathrm{~mol} \mathrm{~L}^{-1} \mathrm{HNO}_{3}$ and $10-15 \mathrm{~mL}$ of $\mathrm{HNO}_{3}$. Thus, the optimum conditions were: $\mathrm{pH} 4.5$ and $10-15 \mathrm{~mL}$ of $1 \mathrm{~mol} \mathrm{~L}^{-1} \mathrm{HNO}_{3} .10 \mathrm{~mL}$ were selected to diminish the elution volume.

\section{Analytical performance}

\subsection{Reusability and maximum capacity of the disk}

The reusability and stability of the modified disk was tested by monitoring recovery of copper ions for several cycles. It was found that the use of the same disk modified with $2.5 \mathrm{mg}$ of PSH 


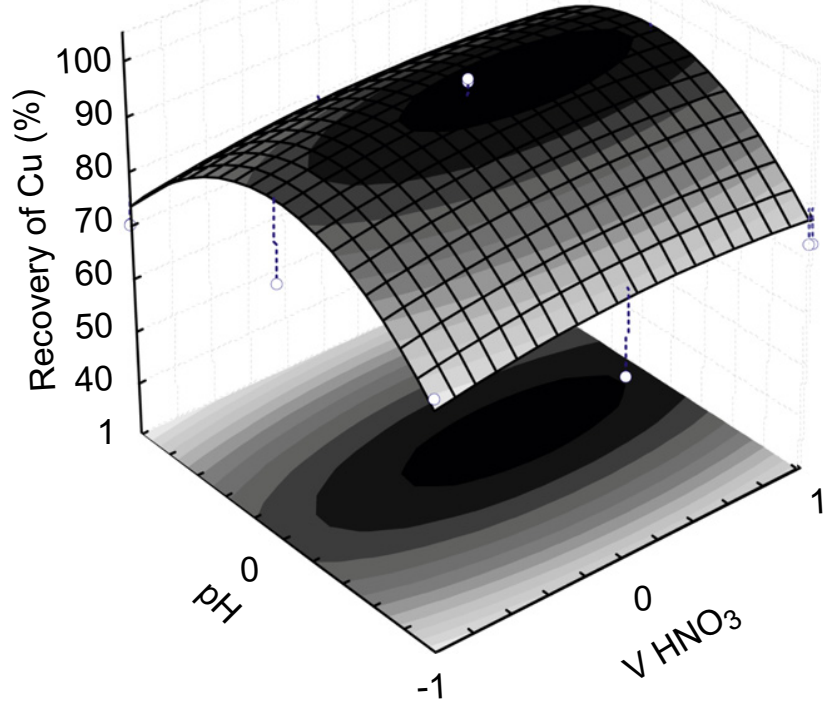

Fig. 5. Response surface plots (3D) showing the effect of $\mathrm{pH}$ and volume of $\mathrm{HNO}_{3}$.

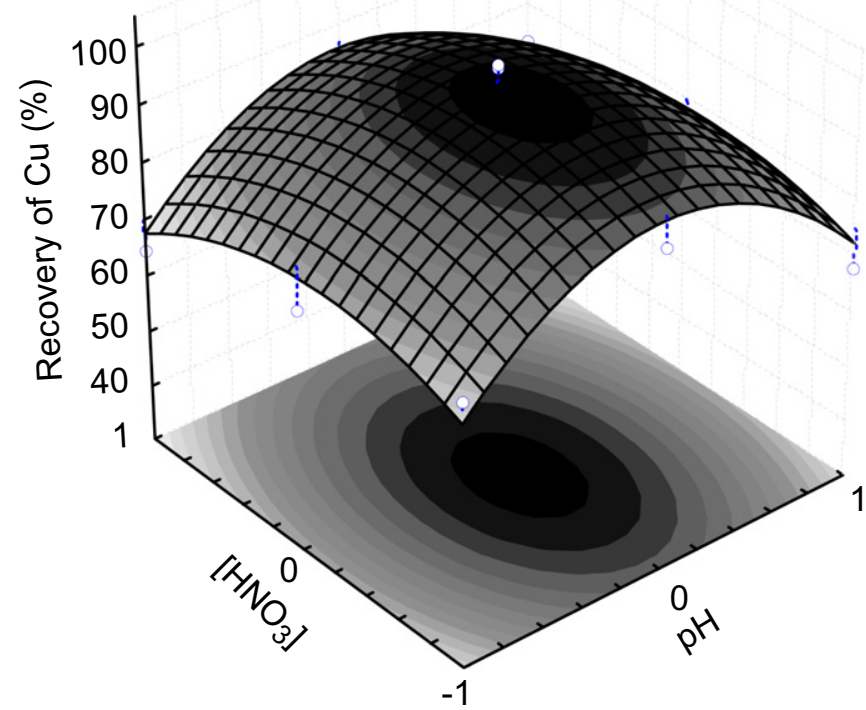

Fig. 6. Response surface plots (3D) showing the effect of $\mathrm{pH}$ and concentration of $\mathrm{HNO}_{3}$.

resulted in no change in the recovery of $40 \mu \mathrm{g} \mathrm{L}^{-1} \mathrm{Cu}$ (II) ion for at least 20 times with a RSD of $1.24 \%(n=20)$. This indicates that the modified disk has a good reusability for continuously usage.

The maximum capacity of the membrane disk was determined by passing $500 \mathrm{~mL}$ of an aqueous solution containing $350 \mu \mathrm{g}$ copper at $\mathrm{pH} 4.5$ through the disk, followed by determination of the retained metal ions by FAAS. The maximum capacity was found to be $65.6 \pm 2.1 \mu \mathrm{g}$ of copper ion on the disk modified with $2.5 \mathrm{mg}$ of $\mathrm{PSH}$. The linear dynamic range of the proposed method for $\mathrm{Cu}(\mathrm{II})$ ions was found in a concentration range of $1-60 \mu \mathrm{g} \mathrm{L}^{-1}$, being very appropriate for copper analysis in water samples. The correlation

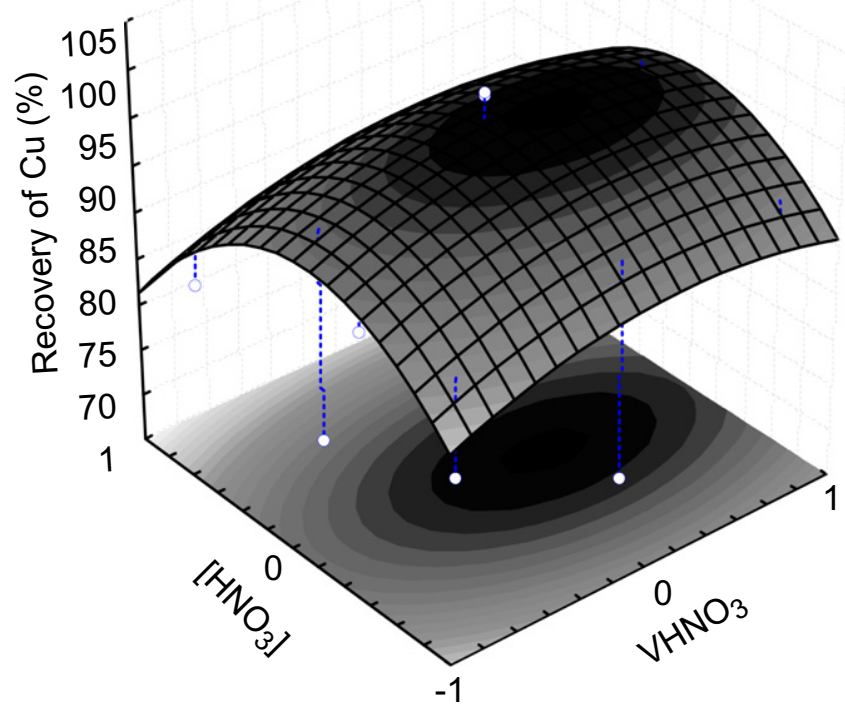

Fig. 7. Response surface plots (3D) showing the effect of concentration and volume of $\mathrm{HNO}_{3}$.

coefficient and equation of the linear regression $(n=10)$ were $R^{2}=0.9982$ and Absorbance $(\lambda=324.8 \mathrm{~nm})=0.0038+0.0047[\mathrm{Cu}(\mathrm{II})]$ $\left(\mu \mathrm{g} \mathrm{L}^{-1}\right)$, respectively.

\subsection{Break-through volume}

The break-through volume was checked by dissolving $5 \mu \mathrm{g}$ of copper in different volumes $(50,100,250,500,750,1000 \mathrm{~mL})$ of aqueous phase. The recovery of copper was tested following the proposed procedure. It was observed that the sorption of copper was quantitative for the studied range, being the breakthrough volume of $1000 \mathrm{~mL}$. Thus, a preconcentration factor of 100 using $10 \mathrm{~mL}$ of eluent was easily achievable being comparable with other SPE methods.

\subsection{Reproducibility and limit of detection}

The reproducibility of the proposed method for the extraction and determination of copper was investigated and the recovery average of metal ion obtained from ten replicate experiments using different disks was found to be $99.0 \pm 2.1 \%$ for $40 \mu \mathrm{g} \mathrm{L}^{-1}$ $\mathrm{Cu}(\mathrm{II})$ in the sample. The precision of the method calculated by using the student's $t$ test for these ten replicates was $1.5 \%$ at confidence level of $95 \%$.

The detection limit (DL) of the method, calculated as three times the standard deviation of blank samples $(n=5)$, was $4 \mathrm{ng} \mathrm{L}^{-1} \mathrm{Cu}(\mathrm{II})$ and the quantification limit (QL), calculated as 10 times the standard deviation, was $14 \mathrm{ng} \mathrm{L}^{-1} \mathrm{Cu}(\mathrm{II})$ [29].

\subsection{Effect of diverse ions on sorption of copper}

In order to investigate the selective separation and determination of copper from samples containing diverse ions, aqueous solutions (500 mL) containing $20 \mu \mathrm{g} \mathrm{Cu}(\mathrm{II})$ and different inorganic salts present in seawater (synthetic seawater composition) were 
taken and the proposed procedure was followed. Furthermore, the influence of other trace metals present in seawater was evaluated using higher concentrations as the usually found in

Table 4

Recovery of copper ions from binary mixtures with inorganic salts presented in seawater [30] $\left(20 \mu \mathrm{g} \mathrm{Cu}(\mathrm{II}) ; V_{\text {sample }}=500 \mathrm{~mL}\right)$.

\begin{tabular}{|c|c|c|}
\hline Inorganic salt & Concentration $\left(\mathrm{g} \mathrm{L}^{-1}\right)$ & $\% \mathrm{Cu}(\mathrm{II})$ recovery \\
\hline $\mathrm{NaCl}$ & 23.94 & 99.3 \\
\hline $\mathrm{MgCl}_{2} \cdot 6 \mathrm{H}_{2} \mathrm{O}$ & 10.83 & 96.7 \\
\hline $\mathrm{Na}_{2} \mathrm{SO}_{4}$ & 3.99 & 99.6 \\
\hline $\mathrm{CaCl}_{2} \cdot 4 \mathrm{H}_{2} \mathrm{O}$ & 2.12 & 100.1 \\
\hline $\mathrm{KCl}$ & 0.677 & 98.5 \\
\hline $\mathrm{NaHCO}_{3}$ & 0.196 & 99.4 \\
\hline $\mathrm{KBr}$ & 0.098 & 100.8 \\
\hline $\mathrm{H}_{3} \mathrm{BO}_{3}$ & 0.027 & 102.7 \\
\hline $\mathrm{SrCl}_{2} \cdot 6 \mathrm{H}_{2} \mathrm{O}$ & 0.024 & 99.3 \\
\hline $\mathrm{NaF}$ & 0.003 & 100.8 \\
\hline
\end{tabular}

Table 5

Recovery of copper ions from binary mixtures with trace metals presented in seawater [30] $\left(20 \mu \mathrm{g} \mathrm{Cu}(\mathrm{II}) ; V_{\text {sample }}=500 \mathrm{~mL}\right)$.

\begin{tabular}{clcr}
\hline Metal ion & $\begin{array}{l}\text { Concentration } \\
\left(\mu \mathrm{g} \mathrm{L}^{-1}\right)\end{array}$ & $\begin{array}{l}\text { Cu:Metal } \\
\text { Concentration } \\
\text { ratio }\left(\mu \mathrm{g} \mathrm{L}^{-1}: \mu \mathrm{g} \mathrm{L}^{-1}\right)\end{array}$ & $\begin{array}{c}\text { \% Cu(II) } \\
\text { recovery }\end{array}$ \\
\hline $\mathrm{Al}(\mathrm{III})$ & 2.70 & 14.8 & 99.2 \\
$\mathrm{Fe}(\mathrm{III})$ & 5.58 & 7.2 & 101.5 \\
$\mathrm{Mn}(\mathrm{II})$ & 5.49 & 7.3 & 99.8 \\
$\mathrm{Ni}(\mathrm{II})$ & 5.87 & 6.8 & 99.3 \\
$\mathrm{~V}(\mathrm{~V})$ & 5.09 & 7.9 & 100.5 \\
$\mathrm{Zn}(\mathrm{II})$ & 6.54 & 6.1 & 99.2 \\
$\mathrm{~Pb}(\mathrm{II})$ & 6.22 & 6.4 & 99.6 \\
$\mathrm{Bi}(\mathrm{III})$ & 0.63 & 63.5 & 99.2 \\
$\mathrm{Cd}(\mathrm{II})$ & 0.34 & 117.6 & 101.2 \\
$\mathrm{Co}(\mathrm{II})$ & 0.18 & 222.2 & 99.7 \\
$\mathrm{Tl}(\mathrm{I})$ & 0.61 & 65.6 & 99.4 \\
\hline
\end{tabular}

Table 6

Determination of $\mathrm{Cu}(\mathrm{II})$ ions in certified reference water (TM-DWS-2, lake water) and real seawater (from southwest coast of Spain) by the proposed solid-phase extraction method $(n=2)$.

\begin{tabular}{lcll}
\hline Sample & $\begin{array}{l}\mathrm{Cu}(\mathrm{II}) \text { concentration } \\
\left(\mu \mathrm{g} \mathrm{L}^{-1}\right)\end{array}$ & $\begin{array}{l}\mathrm{Cu}(\mathrm{II}) \text { found by the } \\
\text { proposed method }\left(\mu \mathrm{g} \mathrm{L}^{-1}\right)\end{array}$ & $\begin{array}{l}\text { Relative } \\
\text { error }(\%)\end{array}$ \\
\hline TM-DWS-2 & $168 \pm 7.1^{\mathrm{a}}$ & $172.7 \pm 2.3$ & 2.8 \\
Seawater 1 & $13.83 \pm 0.51^{\mathrm{b}}$ & $13.97 \pm 0.28$ & 1.0 \\
Seawater 2 & $26.11 \pm 0.63^{\mathrm{b}}$ & $26.49 \pm 0.12$ & 1.5 \\
\hline
\end{tabular}

${ }^{\text {a }}$ Certified value.

b Determination by ASV [31]; $n=4$. this kind of samples [30]. The results summarized in Tables 4 and 5 showed that $20 \mu \mathrm{g}$ of $\mathrm{Cu}(\mathrm{II})$ ions in the binary mixtures are retained quantitatively by the PSH-modified membrane disk, indicating the applicability of this method to complex samples.

\section{Analytical applications}

\subsection{Method validation and analysis of seawater}

The accuracy of the method was evaluated by the determination of $\mathrm{Cu}(\mathrm{II})$ in a certified reference lake water TM-DWS-2. The method was also applied successfully to the analysis of dissolved $\mathrm{Cu}$ (II) in two real seawater samples collected from the southwest coast of Spain (Huelva Estuary). Samples were filtered and UV digested in order to remove suspended and organic matter. The results (Table 6) showed a very good agreement between the experimental and certified values for reference water with a relative error of $2.8 \%$. Measurements of $\mathrm{Cu}$ (II) ion in two seawater samples obtained by the proposed method were also compared which those obtained by differential pulse anodic stripping voltammetry (DPASV) (Application Bulletin No. 231/2e; B12916, Metrohm) [31]. The relative error for seawater samples (1 and 2) were 1 and $1.5 \%$, respectively. In both studies, significant differences at $95 \%$ confidence limit were not found.

\subsection{Comparison with other SPE methods for copper analysis in seawater}

Table 7 shows a comparison of SPE methods for copper analysis in seawater in terms of detection limit, reusability and range of linearity. As can be seen, the method presented in this paper shows a very high sensibility, a significant reusability and a good range of applicability, being suitable for low levels of copper in water samples such as seawater.

\section{Conclusions}

An accurate, reproducible and inexpensive method for preconcentration and determination of trace amount of copper ion was developed. A preconcentration factor of 100 could be achieved by this method which allows determining the copper content in highly diluted samples by conventional flame atomic absorption spectrometry. The method can selectively separate $\mathrm{Cu}$ (II) ion from other metal ions, being successfully applied to the separation and determination of copper in water samples with high saline matrix, such as seawater.

Table 7

Summary of SPE methods for copper analysis in seawater and other samples using membrane disks and AAS determination.

\begin{tabular}{|c|c|c|c|c|c|c|}
\hline $\begin{array}{l}\text { Solid } \\
\text { support }\end{array}$ & Immobilized reagent & $\begin{array}{l}\mathrm{DL} \\
\left(\mu \mathrm{g} \mathrm{L}^{-1}\right)\end{array}$ & $\begin{array}{l}\text { Reusability } \\
\text { (no. cycles) }\end{array}$ & $\begin{array}{l}\text { Range } \\
\left(\mu \mathrm{g} \mathrm{L}^{-1}\right)\end{array}$ & Application & Ref. \\
\hline \multirow[t]{2}{*}{ C-18 silica } & 5-tert-butyl-2-hydroxy-benzaldehyde oxime (L1) & 0.29 & \multirow[t]{2}{*}{-} & $2.5-2847.2$ & \multirow{2}{*}{$\begin{array}{l}\text { Tap water, spring water and sea } \\
\text { water }\end{array}$} & \multirow[t]{2}{*}{ [32] } \\
\hline & 3,5-di-tert-butyl-2-hydroxy-benzaldehyde oxime (L2) & 0.25 & & $2.5-3825$ & & \\
\hline C-18 silica & $N, N^{\prime}$-disalicylideneethylenediamine & 0.005 & 14 & - & $\begin{array}{l}\text { Tap water, snow water, rain } \\
\text { water, sea water }\end{array}$ & [33] \\
\hline C-18 silica & 1,5-diphenylcarbazide & 0.005 & 15 & - & $\begin{array}{l}\text { Tap water, snow water, rain } \\
\text { water, sea water }\end{array}$ & {$[34]$} \\
\hline C-18 silica & $\begin{array}{l}\text { 3-\{2-[2-(2-hydroxyimino-1-methyl-propylideneamino)- } \\
\text { ethylamino]-ethyl-imino\}-butan-2-one oxime }\end{array}$ & 0.17 & - & - & $\begin{array}{l}\text { Tap, snow, river, rain, spring, } \\
\text { mineral and seawater }\end{array}$ & {$[35]$} \\
\hline C-18 silica & (2,20-[1,2-ethanediyl bis(nitriloethylidyne)] bis(1-naphthalene) & 0.004 & - & - & Tap, snow, rain, seawater & {$[36]$} \\
\hline SDB & Pyridoxal salicyloylhydrazone (PSH) & 0.004 & 20 & $1-60$ & Lake and seawater & This work \\
\hline
\end{tabular}




\section{Acknowledgment}

This work has been supported by the grant "Formación de Profesorado Universitario", from the Ministerio de Ciencia e Innovación for M. Díaz-de Alba.

\section{References}

[1] T.R. Crompton, Toxicants in the Aqueous Ecosystem, Wiley\&Sons, New York, 1997.

[2] L. Yuan, S.H. Huo, X.N. Ren, H. Chen, Chin. Chem. Lett. 19 (2008) 92-94

[3] M. Ghaedi, F. Ahmadi, A. Shokrollahi, J. Hazard. Mater. 142 (2007) 272-278.

[4] M. Ghaedi, A. Shokrollahi, F. Ahmadi, H.R. Rajabi, M. Soylak, J. Hazard. Mater. 150 (2008) 533-540.

[5] A.N. Anthemidis, K.G. Ioannou, Talanta 79 (2009) 86-91.

[6] A. Efendioğlu, M. Yağan, B. Batı, J. Hazard. Mater. 149 (2007) 160-165.

[7] T. Nakai, Y. Murakami, Y. Sasaki, S. Tagashira, Talanta 66 (2005) 45-50

[8] A. Aouarram, M.D. Galindo-Riaño, M. García-Vargas, M. Stitou, F. El Yousfi, Talanta 71 (2007) 165-170.

[9] J.P. Xiao, Q. Zhou, H. Bai, Chin. Chem. Lett. 18 (2007) 714-717.

[10] J. Otero-Romaní, A. Moreda-Piñeiro, A. Bermejo-Barrera, P. Bermejo-Barrera, Anal. Chim. Acta 536 (2005) 213-218.

[11] M. Karve, R.V. Rajgor, J. Hazard. Mater. 166 (2009) 576-580.

[12] M.H. Mashhadizadeh, M.S. Azimi, M. Pesteh, I. Sheikhshoaei, M.M. Ardakani, M.A. Karimi, Spectrochim. Acta Part B 63 (2008) 889-892.

[13] S.A.M. Fathi, M.R. Yaftian, J. Hazard. Mater. 164 (2009) 133-137.

[14] A.A. Hill, R.J. Lipert, M.D. Porter, Talanta 80 (2010) 1606-1610.

[15] D.B. Gazda, J.S. Fritz, M.D. Porter, Anal. Chim. Acta 508 (2004) 53-59.

[16] C.F. Poole, Solid-phase extraction with discs, in: I. Wilson, C.F. Poole, M. Cooke (Eds.), Encyclopedia of Separation Science, Academic Press, Amsterdam, 2000, pp. 4141-4148.

[17] J.S. Fritz, M.P. Arena, S.A. Steiner, M.D. Porter, J. Chromatogr. A 997 (2003) 41-50.
[18] M.K. Rofouei, M. Payehghadr, M. Shamsipur, A. Ahmadalinezha, J. Hazard Mater. 168 (2009) 1184-1187.

[19] A.M.H. Shabani, S. Dadfarnia, F. Motavaselian, S.H. Ahmadi, J. Hazard. Mater. 162 (2009) 373-377.

[20] A.S.A. Zidan, Phosphorus, Sulfur Silicon Relat. Elem. 178 (2003) 567-582.

[21] M. Gallego, M. Valcárcel, M. García-Vargas, Anal. Chim. Acta 138 (1982) 311-320 1982.

[22] J. Vicente-Martorell. Desarrollo de metodología de análisis simultáneo para la monitorización de $\mathrm{Fe}, \mathrm{Al}$ y $\mathrm{Cu}$ en conducciones de plantas desaladoras. Tesis de Licenciatura 2007. Servicio de Publicaciones de la Universidad de Cádiz. ISBN: 978-84-691-4398-8.

[23] M. Gallego, M. Valcárcel, M. García-Vargas, Analyst 108 (1983) 92-98.

[24] M. Gallego, M. Valcárcel, M. García-Vargas, Mikrochim. Acta 79 (1983) 289-297.

[25] A. Aouarram, M.D. Galindo-Riaño, M. García-Vargas, M. Stitou, F. El Yousfi, E. Espada-Bellido, Talanta 82 (2010) 1749-1756.

[26] D.C. Montgomery, Diseño y análisis de experimentos, Grupo Editorial Iberoamérica, S.A., México, 1991, p. 265.

[27] B. Welz, Atomic Absorption Spectrometry, VCH, Amsterdam, 1985.

[28] G.W. v anLoon, S.J. Duffy, Environmental Chemistry. A Global Perspective, third ed., Oxford Univ. Press, New York, 2011, p 292-316.

[29] M. Valcárcel, Principios de Química Analítica, Springer, Barcelona, 1999, pp 80.

[30] K. Grasshoff, M. Ehrhardt, K. Kremling, Methods of Seawater Analysis, second ed., Verlag Chemie, Weinheim, 1983.

[31] Metrohm . Determination of Zinc, Cadmium, Lead, Copper, Thallium, Nickel and Cobalt in Water Samples after DIN 38406-E16. Application Bulletin No. 231/2e; B12916, 1990.

[32] M.H. Dindar, S.A.M. Fathi, M.R. Yaftian, N. Noushiranzadeh, J. Hazard. Mater. 179 (2010) 289-294.

[33] A. Moghimi, Chin. J. Chem. 25 (2007) 1842-1848.

[34] A. Moghimi, Chin. J. Chem. 25 (2007) 1663-1668.

[35] Ö. Dalman, S. Karabücek, A. Demirak, M. Tüfekci, Turk. J. Chem. 27 (2003) 649-656.

[36] M. Shamsipur, A.R Ghiasvand, H. Sharghi, H. Naeimi, Anal. Chim. Acta 408 (2000) 271-277. 